\title{
Correction
}

\section{Respiratory Variation in Echocardiographic Dimensions \\ of Left and Right Ventricles in Normal Children}

\section{The Role of the Interventricular Septum}

Bessie L. Lendrum, Avinash M. Mondkar, J. Brian Harris,

Beverly Smulevitz, and Ian Carr

Ped Cardiol 1:39-45, 1979/80

\section{Before correction}

$$
\text { SUMMARY .......... }
$$

The mean inspiratory increase in RVD was $+3.37 \mathrm{~mm} \pm 0.23 \mathrm{~mm} \mathrm{SE}$ and decrease in LVD was $-3.71 \mathrm{~mm} \pm 0.32 \mathrm{~mm}$. This difference was not statistically significant $(p<0.001)$.

\section{After correction}

\section{SUMMARY ..........}

The mean inspiratory increase in RVD was $+3.37 \mathrm{~mm} \pm 0.23 \mathrm{~mm}$ SE and decrease in LVD was $-3.71 \mathrm{~mm} \pm 0.32 \mathrm{~mm}$. The absolute difference was not statistically significant. 